\title{
The Results of Lateral Orbitotomy on Orbital Tumors
}

\author{
Nila F. Moeloek, Ria Mekarwangi, Tetty A Usman, Widiarti P Riono
}

\begin{abstract}
Abstrak
Tumor retrobulbar merupakan salah satu penyakit orbita. Tumor terletak di belakang bola mata, terkukung di antara tulang orbita dan berada di jaringan vital. Gambaran klinisnya berupa eksoftalmos, dapat disertai gangguan gerak bola mata dan penurunan visus. Pembedahan cara orbitotomi lateral lebih ditujukan pada tumor orbita yang berada di daerah temporal, apeks atau sedikit di daerah superior. Tujuan orbitotomi lateral terutama untuk mengangkat tumor secara en toto, memanipulasi organ vital di orbita sedikit mungkin untuk menghindarkan komplikasi gangguan penglihatan.Pembedahan dengan cara ini mungkin mencapai tujuannya, tetapi tampaknya ada pengaruh jenis tumor terhadap keberhasilan pembedahan atau prognosis penderita buruk Bahan penelitian sejumlah 31 pasien yang dilakukan pembedahan orbitotomi lateral di Rumah sakit Dr. Cipto Mangunkusumo, selama periode Januari 1985 - 1992. Kriteria prognosis yang dinilai dalam keberhasilan pengangkatan tumor disertai dengan atau tanpa komplikasi pada berbagai jenis tumor. Dari keberhasilan operasi, ternyata prognosis penderita terbagi dalam 3 kelompok, yaitu :1. Hasil operasi tercapai baik dengan prognosis penderita baik, 2. Hasil operasi tercapai baik, tetapi prognosis penderita buruk, dan 3. Hasil operasi tidak tercapai dan prognosis penderita buruk. Hasil menggambarkan bahwa lokasi, walaupun apeks sekalipun tidak mempengaruhi operasi orbitotomi lateral. Ketidak berhasilan operasi tampaknya dipengaruhi oleh jenis tumor.
\end{abstract}

\begin{abstract}
Retrobulbar tumors are orbital disease processes situated within vital tissue behind the eyeball and confined within the orbital space by the orbital bones. Surgery of the retrobulbar tumors is still difficult to perform, due to the complex anatomy of the orbit which can demand variations in surgical approach. In the case of orbital surgery, a surgeon will do his utmost to reach the apical area. One of the techniques well known in orbital surgery is lateral orbitotomy. This surgery is primarily aimed at removing zygomatic bone constituting the rim of the lateral orbital bone. The principle aim of lateral orbitotomy is to remove the tumor en toto by manipulating vital organs in the orbit as slightly as possible in order to avoid the complications of vision disorder. Thirty-one patients underwent lateral orbitotomy' at the Dr. Cipto Mangunkusumo Hospital and orher hospitals during the period berween January 1985 to July 1982. The criteria for successful surgery consist of the evaluation of successful tumor removal with or without complications. Based on the success of the surgery and prognosis, the patients are divided into three groups, they are:1. Successful surgery; patient prognosis favorable, 2.Successful surgery, patient prognosis dubious and 3. Unsuccessful surgery, patient prognosis unfavorable. However, lateral orbitotomy did not result in complications in several types of tumors although they were located in the apical. This situation shows that even tumors in the apical area do not always affect the success of the lateral orbitotomy; and the failure of the surgery tends to be attributed more to tumor type.
\end{abstract}

Keywords : Orbital tumors, Lateral orbitotomy, Types of tumors

\section{INTRODUCTION}

Retrobulbar tumors are orbital diseases situated within vital tissue behind the eyeball and confined within the orbit by the orbital bones.

Their clinical appearance is often demonstrated by exophthalmos that can be accompanied by deterioration of vision and limitation of ocular movements.
The major difficulties facing patients with orbital tumors for the most part lie in the attempts to perform diagnosis, primarily because retrobulbar tumors are frequently difficult to palpate. This problem was overcome by the invention of Computerized txial Tomography Scanning (CT-scan) as a diagnostic aid in 1972. Utilizing this equipment,all the delicate tissues of the orbit surrounding and bones can be clearly scanned. This equipment is highly valuable in establishing diag- 
noses, and its use can even be expanded to serve as a guidance in planning surgeries.

Surgery of the retrobulbar tumors is still difficult to perform, due to the complex anatomy of the orbit which can demand variations in surgical approach. The principles of surgery, including orbital surgery, presuppose a sufficient space for this undertaking in order to facilitate the removal of the tumor and to diminish the manipulation of other vital tissues. In the case of orbital surgery, a surgeon will do his utmost to reach the apical area. One of the techniques well known in orbital surgery is lateral orbitotomy. This surgery is primarily aimed at removing zygomatic bone constituting the rim of the lateral orbital bone. ${ }^{1,2,3}$

Lateral orbitotomy is primarily directed at orbital tumors situated at the temporal and apical spaces and to some extent at the superior area. In the case of tumors situated nasally it would be advisable to reach the tumor through a transcranial approach. But if lateral orbitotomy is to yield the desired results for this tumor, it should be slighty modified to meet specific needs. ${ }^{3}$

The principle aim of lateral orbitotomy is to remove the tumor en toto by manipulating vital organs in the orbit as possible in order to avoid the complication of vision disorders. Surgery of this kind is also done for biopsy in which the tumor mass can be neither palpated nor clinically diagnosed with supporting diagnostic tools.

Though surgery of this kind might accomplish its aim, a strong mutual relationship exists between the type of tumor and the success of surgery, as well as, the patients' prognosis.

The objective of this study is to perform a re-assessment on the usefulness of lateral orbitotomy based on the success of tumor removal, postoperative complications, and patient prognosis.

\section{MATERIAL AND METHOD}

This study includes data taken from the medical records of patients who had undergone lateral orbitotomy at Dr. Cipto Mangunkusumo Hospital, January 1985 to July 1992. The majority of patients were eye tumor patients who had undergone treatment at the Ocular Tumor Sub Department at the Dr. Cipto Mangunkusumo Hospital. This study covers a treatment period.

Diagnosis of retrobulbar tumor was established. on the basis of clinical examination and supporting examination, of which one was CT-scan examination. Histopathological examination still plays a major role in establishing diagnosis in these patients. The majority of patients underwent lateral orbitotomy with a Wright incision, ${ }^{3}$ while the remainder underwent this orbitotomy with a slight modification, also called the osteoplasty orbitotomy type 2 of Nakamura. ${ }^{4}$

The criteria for successful surgery consist of the evaluation of successful tumor removal with or without complications.

Patient prognosis was determinedon the basis of tumor type and the necessity further treatment.

The data taken into account are :

- tumor removal : tumor can be removed either en toto or in part (excision)

- surgical complications : is there any paresis of eye muscle, orbital hematoma or ptosis

- visual conditions prior to and post surgery

- tumor types based on the histopathologic examination

- further treatment on the basis of tumor types and the patient's prognosis

Based on the success of the surgery and prognosis, the patients are divided into three groups, they are :

1. successful surgery, patient prognosis favorable

2. successful surgery, patient prognosis dubious

3. unsuccessful surgery, patient prognosis unfavorable

The purpose of this three-group division is to reassess the extent to which lateral orbitotomy could best serve its purpose in order that the surgery could be conducted more effectively on certain tumor types.

\section{RESULTS}

Thirty-one patients underwent lateral orbitotomy at the Dr. Cipto Mangunkusumo Hospital and other hospitals during the period between January 1985 to July 1992 They consist of 13 males $(41.9 \%)$ and 18 females $(58.1 \%)$; the youngest patient being 4,5 years old, and the oldest 70 years old, the mode being 31 years old.

The data collected from those who underwent lateral orbitotomy include, the results of tumor removal; surgical complications; resulting visual conditions; the histopathologic results; and the patient's prognosis. These results are evident in the Tables $1,2,3,4$.

\section{DISCUSSION}

During the period of January 1985 to July 1992, lateral orbitotomy was performed on 31 patients with orbital tumors, comprising 13 males and 18 females with the mode age of 31 years. 
Table 1. The success of tumor removal on 31 patients undergoing lateral orbitolomy based on lumor type and their location in the orbit

\begin{tabular}{|c|c|c|c|c|c|c|}
\hline \multirow[t]{2}{*}{ No. Tumor Types } & \multirow[b]{2}{*}{ Apical } & \multirow{2}{*}{$\begin{array}{l}\text { Localion } \\
\text { Temporal }\end{array}$} & \multirow[b]{2}{*}{ Sup } & \multirow{2}{*}{\multicolumn{2}{|c|}{$\begin{array}{c}\text { Removal } \\
\text { en tolo incomplete } \\
\text { removal }\end{array}$}} & \multirow{2}{*}{ Tolal } \\
\hline & & & & & & \\
\hline 1. BMT & - & 4 & - & 4 & - & 4 \\
\hline 2. Neurilemmoma & - & - & 2 & 2 & - & 2 \\
\hline 3. C. Hemangioma & 3 & 1 & - & 4 & - & 4 \\
\hline 4. Dermoid Cyst & - & 1 & - & 1 & - & 1 \\
\hline 5. $\mathrm{ACC}$ & 0 & 5 & - & 4 & 1 & 5 \\
\hline 6. Pseudotumor & 3 & 2 & - & 4 & 1 & 5 \\
\hline 7. Glioma & 2 & - & - & 2 & - & 2 \\
\hline 8. F.Histiocytoma & - & 1 & - & 1 & - & 1 \\
\hline 9. Mal. Lymphoma & - & 1 & - & 1 & - & 1 \\
\hline 10. Meningioma & 2 & - & - & - & 2 & 2 \\
\hline 11. Lymphangioma & 4 & - & - & 1 & 3 & 4 \\
\hline Total & 15 & 14 & 2 & 24 & 7 & 31 \\
\hline \multicolumn{7}{|l|}{ Nole : } \\
\hline B M T & \multicolumn{6}{|c|}{ : Benign mixed tumor (pleimorphic adenoma) } \\
\hline C. Hemangioma & \multicolumn{6}{|c|}{ : Cavemous hemangioma } \\
\hline A C C & \multicolumn{6}{|c|}{ : Adenoid cystic carcinoma of the lacrimal gland } \\
\hline F.Histiocytoma & \multicolumn{6}{|c|}{ : Fibrous histiocyloma } \\
\hline Mal. lymphoma & \multicolumn{6}{|c|}{ : Malignant lymphoma } \\
\hline Sup & \multicolumn{6}{|c|}{ : Superior } \\
\hline
\end{tabular}

Table 2. Orbitotomy complications related to tumor and location

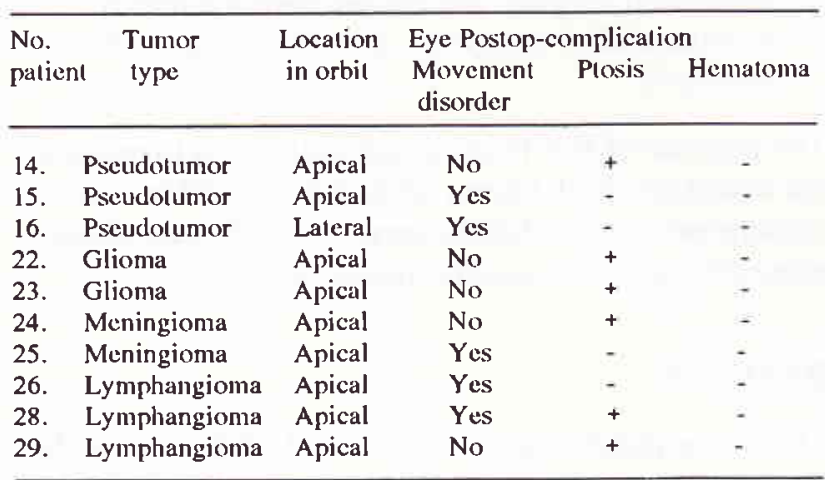

Table 3. The relationship between tumor types and surgical result and the palient's prognosis

\begin{tabular}{llccc}
\hline Group & Tumor lype & Total & $\begin{array}{c}\text { Successful } \\
\text { Surgery }\end{array}$ & $\begin{array}{c}\text { Successful } \\
\text { Prognosis }\end{array}$ \\
\hline A. Successlul & * BMT & 4 & 4 & 3 \\
surgery $\rightarrow$ & * Neurilemmoma & 2 & 2 & 2 \\
Successlul & * C.Hemangiona & 4 & 4 & 4 \\
prognosis & * Dermoid Cyst & 1 & 1 & 1 \\
B. Successful & * Pseudotumor & 5 & 4 & 1 \\
surgery $\rightarrow$ & *ACC & 5 & 4 & 0 \\
Poor & * Glioma & 2 & 2 & 0 \\
prognosis & *F.Histiocyloma & 1 & 1 & 0 \\
& * Mal.lymphoma & 1 & 1 & 0 \\
C. Fajled & & & & 0 \\
surgery $\rightarrow$ & * Meningioma & 2 & 0 & 0 \\
Poor & * Lymphangioma & 4 & 1 & 11 \\
prognosis & & & & \\
\hline Total & & 31 & 24 & \\
\hline
\end{tabular}

Tabel 4. Distribution of visual acuity before to and after surgery and the patient's prognosis

\begin{tabular}{|c|c|c|c|c|c|}
\hline No. & Tumor type & $\begin{array}{l}\text { Pre Op } \\
\text { Vision }\end{array}$ & $\begin{array}{l}\text { Posl Op } \\
\text { Vision }\end{array}$ & Follow up & Prognosis \\
\hline 1. & BMT & $3 / 60$ & $3 / 60$ & Good & Good \\
\hline 2. & BMT & $6 / 5$ & $6 / 5$ & Good & Good \\
\hline 3. & BMT & $5 / 60$ & $6 / 5$ & Recurrent & Poor \\
\hline 4. & $\mathrm{BMT}$ & $1 / 60$ & $6 / 10$ & Good & Good \\
\hline 5. & Neurilemmoma & $6 / 5$ & $6 / 5$ & Good & Good \\
\hline 6. & Neurilenmoma & $6 / 60$ & $6 / 5$ & Good & Good \\
\hline 7. & C.Hemangioma & $6 / 5$ & $6 / 5$ & Good & Good \\
\hline 8. & C.Hemangioma & $6 / 5$ & $6 / 5$ & Good & Good \\
\hline 9. & C.Hemangioma & $2 / 60$ & $6 / 30$ & Good & Good \\
\hline 10. & C.Hemangioma & $6 / 5$ & $6 / 5$ & Good & Good \\
\hline 11. & Dermoid Cyst & $6 / 5$ & $6 / 5$ & Good & Good \\
\hline 12. & Pseudolumor & $6 / 5$ & $6 / 5$ & Good & Good \\
\hline 13. & Pseudotunor & + & + & Squint & Poor \\
\hline 14. & Pscudolumor & $6 / 5$ & $6 / 5$ & Recurrent & Poor \\
\hline 15. & Pscudolunor & $6 / 5$ & $6 / 5$ & Recurrent & Poor \\
\hline 16. & Pseudotumor & $6 / 15$ & $6 / 15$ & Diplopia & $P(x) r$ \\
\hline 17. & $\mathrm{ACC}$ & $4 / 60$ & $5 / 60$ & Excnlcration & Poor \\
\hline 18. & $\mathrm{ACC}$ & $6 / 5$ & $6 / 5$ & $\begin{array}{l}\text { Reluse } \\
\text { exenteration }\end{array}$ & Pour \\
\hline 19. & $\mathrm{ACC}$ & $6 / 5$ & $6 / 5$ & Exenteration & Poor \\
\hline 20. & $\mathrm{ACC}$ & $6 / 5$ & $6 / 5$ & Excnleration & Poor \\
\hline 21. & $\mathrm{ACC}$ & $3 / 60$ & $6 / 5$ & Exenteration & Poor \\
\hline 22. & Glioma & $1 / 60$ & $\mathrm{~N}_{\mathrm{pl}}$ & Enucleation & Poor \\
\hline 23. & Glioma & + & $\mathrm{Npl}$ & Good & Poor \\
\hline 24. & Meningioma & $6 / 20$ & $\mathrm{Npl}$ & Recurrent & P(x)r \\
\hline 25 . & Meningioma & 0 & $\mathrm{Npl}$ & Proplosis + & P(x)r \\
\hline 26. & Lymphangioma & $6 / 30$ & $1 / 60$ & Recurtent & Poor \\
\hline 27. & Lympliangioma & $6 / 30$ & $6 / 7.5$ & Recurrent & Poor \\
\hline 28. & Lymphangioma & $6 / 5$ & $6 / 40$ & Recurrent & Poor \\
\hline 29. & Lymphangioma & $6 / 15$ & $6 / 7.5$ & Recurrent & Poor \\
\hline 30. & F.Histiocyloma & $2 / 60$ & $2 / 60$ & Recurrent & Poor \\
\hline 31. & Malig.Lymphoma & $6 / 5$ & $6 / 5$ & $\begin{array}{l}\text { Chemolherapy+ } \\
\text { Radiotherapy }\end{array}$ & Poor \\
\hline
\end{tabular}

Note: $\quad+$ light perception only
Npl - no light perception

Eleven tumor types were determined through histopathologic examination; i.e. benign mixed tumor, adenoid cystic carcinoma lacrimal gland, neurilemmoma, dermoid cyst, pseudotumor, cavernous hemangioma, glioma, meningioma, lymphangioma, malignant lymphoma, and fibrous histiocytoma.

It is evident from Table I that the lateral orbitotomy procedure is limited to orbital tumors located in the temporal (or lateral), superior, and apical orbital areas. As many as 15 tumors $(48.39 \%)$ were situated in the temporal area. These figures are only slighty higher than those of tumors located in the apical area; i.e., 14 patients $(45.16 \%)$.

It can also be seen in Table 1 that the tumors of 24 patients $(77.4 \%)$ could be removed en toto, while only 7 patients $(22.6 \%)$ had tumors removed through partial excision.

It is also revealed that the tumors situated in the temporal, superior, and apical areas $(77.4 \%)$ could be 
removed en toto through lateral orbitotomy. This success attests the effectiveness of this surgical approach. In the cases of 7 patients $(22.6 \%$ ) where this procedure failed and incomplete removal was performed, the tumor types were adenoid cystic carcinoma, pseudotumor, meningioma, and mostly lymphangioma. The patients suffering from these types of tumors also experienced post surgical complications such as ptosis and disorders of eye movements ( see Table 2). The patients suffering from ptosis and disorders in eyemovement proved to have tumors located primarily in orbital apical area (Table 2). The apical area is where the vital organs converge in close approximation to each other. This anatomical area presents great difficulty in avoiding manipulation of the vital organs during surgery.

However, lateral orbitotomy did not result in complications in several other types of tumors although they were located in the apical. This situation shows that even tumors in the apical area do not always affect the success of the lateral orbitotomy, and the failure of the surgery tends to be attributed more to tumor type.

The discussion of the tumor types will be undertaken on the basis of the three groups demonstrated in Table 3.

\section{A.TUMOR TYPES OF GROUP I : SUCCESSFUL SURGICAL RESULTS AND FAVORABLE PROGNOSIS}

\section{Benign Mixed tumor}

Benign mixed tumors originate in the lacrimal gland, and are frequently referred to as pleomorphic adenomas. This tumor takes the form of a benign mass consisting of epithelium and mesenchyme. ${ }^{5,6}$

The tumor, which is located in the superotemporal area, has a relatively slow and painless growth. Through CT-scan examination it is evident that there exists a spindle-shaped mass clearly defined in the area of the lacrimal gland. ${ }^{5,7}$ The therapy recommended is to remove the tumor en toto, to reduce recurrence.

$\mathrm{Mc} \mathrm{Nab}^{8}$ recommends tumor removal accompanied by periorbita to avoid recurrence. Malignancy often occurs upon recurrence. 5 The prognosis of the patient with this kind of tumor is usually good, if total removal is successful.

From Table 1, four patients were found with benign mixed tumor, that were removed en toto without any postoperative complications. The visual acuity after surgery proved to be better and the patients ${ }^{\circ}$ prognoses were found to be good. Only one patient suffered from recurrence during treatment
(Table 4, case number 3 ). It is difficult to provide a satisfactory explanation in this case, because when the tumor was removed for the first time, the tumor and its capsule appeared to have been removed en toto yet it is quite probable that a small part of the capsule was left during the removal. During repeat surgery it was recognized that the capsule had disrupted, and recurrence was associated with malignant transformation. The patient's prognosis worsened and eventually she passed away.

\section{Neurilemmoma}

Neurilemmoma is a primary peripheral nerve tumor consisting mainly of the proliferation of Schwann's cells. The tumor is encapsulated by neural perineum. 5,6 This tumor is generally found among adults aged between 20 and 27, and no predilection of sex is found. Usually the tumor grows unilaterally without any pain. Proptosis occurs with downward displacement of the eye, because the majority of tumors originate from branches of the supraorbital and supratrochlear nerves in the superior area of the orbit. Through CT-scan examination, the mass appears clearly defined elongated, or fusiform, and its main diameter running anterior-posterior to the orbit. ${ }^{5}$ The patient's prognosis in this case is generally good.

From Table 1, two adult patients were found with neurilemmoma located in the superior orbit. The tumors were removed en toto and no complications were found post operatively. The visual acuity of one of the two patients prior to surgery was poor, but improved post operatively, with a good prognosis.

\section{Cavernous hemangioma}

Cavernous hemangioma is a vascular tumor most frequently encountered in the orbit of adult patients. The tumor is generally unilateral and solitary. Its growth is relatively slow yet progressive. The tumor is encapsulated, possessing no feeding vessels, and is not of regressive nature. Proptosis is generally axial, because tumor locations are mostly at the apical area. ${ }^{5}$ On CT-scan examination the tumor appears as a spindle shaped mass with definite boundaries and is situated within the muscle cone.

The prognosis of patients suffering this kind of tumor is usually good. Cavernous hemangioma is a benign tumor that never turns into malignancy.

Table 1 shows four patients with cavernous hemangioma, of which 3 had tumors located at the apical area, and 1 with the tumor in the lateral area. Ali the tumors were removed en toto, and no complications were found after surgery (table 2 ). It also reveals that 
the vision after surgery was good, and even became increasingly better (Table 4 , cases number 9 ).

\section{Dermoid Cyst}

The cyst walls consist of squamous epithelium and dermis and the lumen contains keratin and hair. Dermoid cysts are usually in the temporal or superonasal areas of the orbit. Their clinical symptoms vary depending on the location and the size of the cyst. The appearances of dermoid cysts on CT-scan are quite characteristic; i.e, lesions appear to be clearly defined with thin walls and the lumen is of low density. ${ }^{9}$ Dermoid cysts located anteriorly can cause defects of the bone to where they are attached, usually in the zygomatic frontal region.

Table 1 shows a patient with a temporally situated dermoid cyst which was removed en toto without any post-operative complications (Table 2). Visual acuity after surgery remained good (Table 4), and the patient's prognosis was equally good.

It is evident from the data collected that the lateral orbitotomy performed in the first group was successful; i.e, tumors were removed en toto without post surgery complications. Even visual acuity showed definite improvement in those cases and in all the patient. Prognoses were favorable except for one patient whose benign mixed tumor recurred. In order to avoid recurrence, Mc Nab emphasizes the necessity of removing tumor along with the periorbital fascia. It is sufficient to say that lateral orbitotomy performed in the first group of tumor types succeeded in accomplishing the purposes of the treatment.

\section{B. THE SECOND GROUP OF TUMOR TYPES : SUCCESSFUL SURGERY WITH DUBIOUS PROGNOSIS}

\section{Adenoid Cystic Carcinoma}

Adenoid cystic carcinoma is a frequently encountered epithelial carcinoma of the lacrimal gland. This kind of tumor is one of the malignant tumors of lacrimal gland that can cause death. ${ }^{9}$ Generally this tumor is found in young adults with symptoms of unilateral proptosis with downward and medial displacement of the eye and is accompanied by pain. The pain indicates the spread of the tumor to the periorbit and nerves. Through CT-scan, it is revealed that the mass is spindle-shaped with irregular boundaries. The bone erosion at the area of the superotemporal orbit is not always distinct except when the mass is relatively large. The prognasis of the patient with malignant tumor of lacrimal gland is usually poor. Recurrence rate is reasonably high, and it frequently invades orbital bones.

As seen in Table 1, five patients were diagnosed histopathologically as having adenoid cystic carcinoma. All the tumors were removed en toto without any post surgery complication (Table 2 ). The patients visual acuity both prior to and after the surgery remained good.

However, because of the poor histologic characteristics of the tumor, and its further growth to stage III and IV, to prolong the patients lives further surgery in the form of orbital exenteration coupled with radiotherapy was necessary. Visual acuity of the patients was lost.

\section{Pseudotumor}

Pseudotumor is not a true neoplasm, but consists of inflammatory cells forming a mass in the orbit. ${ }^{5,6}$

This tumor usually affects young adults but can also affect children. There is no sex prevalence, and the tumor can occur unilaterally or bilaterally.

The clinical appearance is of palpebral edema, conjunctival chemosis, ocular motility disturbances, proptosis, and pain. Occassionally visual reduction or diplopia may occur.

The inflammatory process can involve the whole orbit or certain tissues only, such as the lacrimal gland, extraocular muscles, orbital fat, or vascular tissue.

CT-scan appearances are varied. It could appear to be retrobulbar edema, optic nerve inflammation, muscle enlargement, or an infiltrative mass. ${ }^{10}$

The patient's prognoses is hopeful, yet the preservation of visual acuity largely depends on the extent and the severity of the inflammatory process and the effective response to corticosteroids and radiotherapy.

From Table 1, it is seen that there wure five patients with pseudotumors located at the temporal and apical areas. Tumors located at the temporal area originated from the lacrimal gland and their removal en toto was relatively easy to perform. On the other hand, the en toto removal in the apical area was relatively more difficult, and great care had to be taken. One patient was found to have chronic nyositis of the lateral rectus muscle which on CT-scan examination appeared as a mass. Only an extirpation biopsy was performed via lateral orbitotomy. Further treatment by radiotherapy proved to have no effect, and the patient still complained of diplopia (Table 4, case number 16). In four patients whose tumors were removed en toto, post surgical complications occurred consisting of limited eye movement in one patient and ptosis palpebra in another (Table 2, cases number 14,15). 
Visual acuity both prior to and after the surgery did not change significantly overall. During further treatment it was found that one patient suffered from reccurrence and another from strabismus, while two others had complaints of diplopia (Table 4 , cases number $13,14,15,16)$. It seems that the prognosis for good visual acuity is not very encouraging, while the prognosis for survival remains favorable.

\section{Glioma}

Glioma is a primary tumor of the optic nerve glial cell. ${ }^{5}$ This tumor is most commonly found among children, and comprises $1-2 \%$ of all orbital tumors. Nearly $50 \%$ of the tumors are diagnosed in children aged under 5 . It appears with unilateral proptosis. Bilateral proptosis is a pathognomonic sign of glioma accompained by neurofibroma, and cafe-au-lait spots may be encountered. ${ }^{5,6}$

Management of the tumor varies according to the size and location of the tumor, as well as the visual condition of the patient. It is difficult to assess the patient's prognosis due to the variation of the disease's history. Generally, the visual prognosis is discouraging, while the life prognosis depends on the extension of tumor invasion intracranially. On CT-scan the optic nerve appears enlarged and intracranial extension of the tumor through the optic foramen can be seen.

Table 1 reveals two five year old girls with glioma. Their tumors were removed in toto, but post surgical complication occurred consisting of limited eye movement and ptosis. Visual acuity definitely worsened. It was also not possible to maintain the eyes in good condition, which finally neccessitated enucleation of the eye and repair of the ptosis.

\section{Fibrous Histiocytoma}

Fibrous histiocytoma, frequently referred to as fibro xanthoma, is a tumor of histiocytes usually intermixing with fibroblasts or fibrocyles. ${ }^{5}$ Its clinical appearance is generally unilateral proptosis, with the tumor situated at the superior or nasal area of orbit. This tumor tends to cause reduction of vision on conjunctival chemosis and paralysis of ocular muscles. On CT-scan it appears as a round-shaped mass with either clear, conjunctival chemosis and paralysis of ocular muscles definite or irregular boundaries, and it is difficult to differentiate it from neurilemmoma, cavernous hemangioma, or hemangiopericytoma. Bone erosion is rarely encountered, except in the advanced stages. $^{5}$

The surest way to deal with this kind of tumor is to remove all the tumor tissue. Should a recurrence occur, further excision must cover a wider area, and if necessary an orbital exenteration must be resorted to in this case. During the recurrence, the tumor will tend to be more aggressive and malignant. Generally, radiotherapy carried out on this tumor does not yield good results, and its recurrency rate is high. Death could follow due to a direct metastases intracranially.

Table 1 shows one patient who underwent lateral orbitotomy due to fibrous histiocytoma. The tumor was situated at the apex and was removed in toto without post surgery complications. The visual acuity both prior to and after surgery remains relatively unchanged (Table 4). In view of the possibility of the recurrence of this tumor, the patient's prognosis remains dubious.

\section{Malignant Lymphoma}

Lymphoid tumors generally originate in lymph glands, yet they can also develop outside lymph glands, such as those found in the orbit. ${ }^{5,6}$ Clinically lymphoid tumors usually present as progressive proptosis, yet this kind of tumor is not accompanied by pain, disorders in ocular motility, reduction in vision, or enlargement of the lacrimal gland.

It is difficult to differentiate malignant lymphoma originating in the lacrimal gland from epithelial primary tumor of the lacrimal gland. ${ }^{5}$ On CT-scan the tumor appears oval or elongated and grows along the rectus muscle. Most tumor of this kind are confined to soft tissue of the orbit and do not cause bone erosion. 5

Table 1 reveals one patient who underwent lateral orbitotomy for malignant lymphoma located at the lacrimal gland. The tumor was removed completely without post surgery complications. The visual acuity of the patient remained unaffected, yet because the patient's condition necessitated cytostatic treatment and radiotherapy, his prognosis depends on the extent of the disease.

The second group of tumors exhibit reasonably good surgical results in which the tumors were removed en toto. However on follow-up it was shown that the patients had poor prognoses. Performing lateral orbitotomy on these cases should be limited. In the case of adenoid cystic carcinoma, with the tumor at an early stage and of small size, when it is still possible to remove the orbital tissue around the tumor without resorting to exenteration, a lateral orbitotomy could be utilized. If the disease has reached and advanced stage, an exenteration is more appropriate. Appropriate evaluation would include biopsy to determine diagnosis first. Fine needle aspiration biopsy is recommended in an effort to avoid surgery. This method is also effective in dealing with pseudotumors in order to ensure a definite diagnosis prior to treatment 
with corticosteroid or radiotherapy. Lateral orbitotomy can be utilized if necessary, yet it must be done by taking into account any possible complications. In the cases of glioma, fibrous histiocytoma, and malignant lymphoma, lateral orbitotomy can be carried out to remove the tumor. It should be borne in mind that ultimately in the patients prognosis may be a function of the nature of the tumor.

\section{THE THIRD GROUP OF TUMORS : THE RESULTS OF SURGERY ARE NOT ACCOMPLISHED, AND THE PATIENTS PROGNOSIS UNFAVORABLE}

\section{Lymphangioma}

Lymphangioma is a benign tumor present since birth. It is slowly progressive, so that clinical signs are only apparent after several months or several years after birth. Proptosis is found unilaterally. Blood filled multilocular cysts are frequently encountered.

Hemorrhage into the orbit results in a mass usually known as a "brown cyst". Pressure on the eye will cause secondary glaucoma, edema of the optic disc, and loss of vision. On CT-scan, a multilocular cystic mass is seen within orbital tissue with undefined irregular boundaries, of high density without contrast, and without changes in density after contrast injection.

Four patients with lymphangioma underwent lateral orbitotomy, as can be seen in the Table I. Only one tumor was completely removed, and complications occurred in three, such as restriction of ocular movement in two and ptosis in another two. Extirpation of this tumor is difficult, even with gradual,part by part excision it appears impossible to avoid post operative complications. No improvement of vision occured after surgery, and prognosis is doubtful in respect to the progressive nature of the tumor.

It is difficult to determine the best way to deal with this type of tumor because treatment will depend on such factors as visual acuity, and size as well as location of the tumor. If the tumor is confined to the optic nerve and does not disturb vision, immediate surgery is not necessary. ${ }^{5}$ On the other hand, if the tumor shows any progressivity and sharp reduction in vision occurs, surgery is called for, and the type of surgery recommended is lateral orbitotomy. The prognosis for visual acuity of the patient with tumor located at the apical area is usually discouraging.

\section{Meningioma}

Meningioma is a tumor originating from the meningothelial cells of the arachnoid layers. ${ }^{3,5}$ The arach- noid can be found in the orbit as the outer layers of the optic nerve. Primary meningioma arises from the optic nerve arachnoidal layer within the orbit of optic foramen. Secondary meningioma arises from the intracranial arachnoid layer contiguous to the orbit.

Primary meningioma occurs in the 30 - 50 years age group, and secondary meningioma usually present in the fifth decade. This tumor is most often found in women, and usually Caucasion. ${ }^{5,6}$

Meningioma is a slowly progressive growing tumor of local malignancy, without metastases. ${ }^{5}$ The clinical characteristic of meningioma is slow but progressive unilateral loss of vision.

CT-scan examinations are important to evaluate the extent of the tumor. On CT-scan a high density lesion can be seen whose density increases upon injection of contrast. The tumors may have regular or irregular boundaries.

Table 1 reveals two patient with meningioma who underwent lateral orbitotomy. The tumors were not removed en toto, and even excision was difficult because of the hard consistency of the tumor and its tendency to bleed. Complication occuring after surgery in two patients were restricted eye movement and ptosis. Visual acuity after surgery progressively deteriorated. Recurrences during follow up led to semi-exenteration of the orbit.

The above data show that surgical results in the third group on lymphangioma and meningioma are not favorable. Tumors could not be completely removed and surgical complications frequently occur such as retricted eye movement and ptosis. Lateral orbitotomy on these cases should be carefully considered in respect to the difficulty of the operation, the surgical complications that may occur, and the poor prognosis of the patient. In the case of lymphangioma and meningioma, the lateral orbitotomy is not adequate to yield the desired results. There are still numerous difficulties to be faced in this group if lateral orbitotomy is to be performed. Recently an alternative method using $\mathrm{CO}_{2}$ laser, has been devised.

Chard ${ }^{11}$ has already used $\mathrm{CO}_{2}$ laser therapy on a case of meningioma of the sphenoid bone by first exposing the field of operation by means of lateral orbitotomy. The tumor was destroyed by $\mathrm{CO}_{2}$ laser burning. The major advantage of this therapy lies in its capacity to eliminate the possible hemorrhage frequently interfering in the removal of the tumor.

\section{CONCLUSION}

In the view of the results of this review of lateral orbitotomy conducted on patients with tumors of the above mentioned types and the associates patient's 
prognoses, it is advisable that this kind of surgery be given careful consideration before it is attempted in order to ensure the desired results.

In the light of all these possibilities, it seems that lateral orbitotomy still has a place in dealing with this group of tumors, yet it would surely be more effective if this kind of surgery is coupled with other therapy, such as $\mathrm{CO}_{2}$ laser.

\section{REFERENCES}

1. Kronlein RU. Zur Pathologie und operativen behandlung der dermoidcysts der Orbita. bruns klin Chir 1982;4 : 149.

2. Henderson JW. orbital tumors. Brian C Decker, a Division of Thieme-Stratton Inc. New York, 1980

3. Bonavolonta G. Evoluzione dell'orbitotomia temporale. Att 610 Congr. Societa Oftalmologica Italiana, Rome, 1981.
4. Nakamura y. Osteoplastic Orbitotomy for Orbital tumor surgery, 5th International Symposium on Orbital Disorders, September 1985, Amsterdam. Orbit 1986; $5: 235$ - 7.

5. Shield JA. Diagnosis and Management of Orbital Tümors. Philadelphia : WB Saunders, 1989.

6. Henderson JW, Farrow GM, Devine KD, Miller RH. Orbital Tumors. Philadelphia: WB Saunders, 1973.

7. Kincaid MC, Green WR. Diagnostic Methods in Orbital Disease.Ophthalmology 1984; 91: 719-25.

8. McNab AA. lacrimal fossa lesions clinical features of over 400 consecutive cases. Satellite Symposium on Intraocular and Adnexal Tumors, and Orbital Diseases, Bali 1990

9. Grove AS. Giant Dermoid Cyst of the Orbit. Ophthalmologica 1979; 86: 1513-20.

10. Ensmann D, Donaldson Dermoid SS, Marshall WH, Kriss JP. Computed Tomografi in Orbital Pseudotumor. Radiology 1976; 120: 597-601.

11. Char DH. Advances in orbital Tumors Diagnosis and Therapy. XIII Congress of Asia Pasific Academy of Ophthalmology, Kyoto, 1991. 